\title{
Reflecting on nineteen years as editor of the Japanese Journal of Political Science (2000-2018)
}

\author{
Takashi Inoguchi \\ J. F. Oberlin University, Tokyo, Japan \\ Corresponding author. Takashi Inoguchi, Email: inoguchi@ioc.u-tokyo.ac.jp
}

My editorship of the Japanese Journal of Political Science will end as of 31 December 2018. Please allow me to attempt a brief professional-cum-personal reflection on my editorial experience.

Introduction to Editing: When I landed at the Logan Airport in Boston in the summer of 1970 to pursue a graduate degree at Massachusetts Institute of Technology, I never imagined that I would be the editor of an academic journal 30 years thereafter. In the late 1990s, when Cambridge University Press approached me to undertake the task of editing a new journal in Tokyo, the idea was a challenge to me. By then, I had had some experience in journal editing, (1) International Organization under Peter J. Katzenstein (Ithaca) and Stephen D. Krasner (Palo Alto) in the 1980s, (2) Journal of Japanese Studies under Susan Hanley and the late Kozo Yamamura (Seattle) in the 1980s and 1990s, and (3) Government and Opposition under the late Ghita Ionescu (Manchester) in the 1990s. Also, by then, I had published a co-edited volume with Daniel Okimoto under Yasusuke Murakami's and Hugh Patrick's overall editorship in 1988 with Stanford University Press and my co-edited book manuscript with Michael Cox and G. John Ikenberry, American Democracy Promotion, had been accepted to be published in 2000 by Oxford University Press.

Editorial Team and Principles: The editorial team would not have been easy to form, if it had been confined to a Japanese search. Although the idea came through the Leviathan, a Japanese politics journal, I knew that they were not interested in undertaking the editing of the journal alone. Therefore, my team was an international one composed of those eminent scholars whom I had met through my editing experiences over the preceding 20 years. The first adjective attached to the journal does not mean that the geographical scope of the journal is Japan but that the editor is Japanese. The subjects the journal covers are open to political scientists from different schools of thought. One element that became clear through the journal's acceptance and eventual publication of articles is that it encouraged submitters to be deep rooted in their conceptualization, to be innovative in method, and to be interesting in their arguments.

Citations and Submissions: Nevertheless, what has come to count is citation frequency. Google Scholars Citation of articles and the impact factor of the journal came to our attention as well. Given American hegemony in the political science world, the journal never registered very high figures in this respect. However, a few years ago, the journal registered a surprising and welcomed impact factor: this journal registered an impact factor figure on par with its counterparts in Australia and Canada, two English-speaking societies. In terms of the source of submitting authors, the journal registered $40-50 \%$ from the United States and the European Union, 40-50\% from Asia and the Indo-Pacific, and some $10 \%$ from Japan. This distribution is sound in the sense that Asian authors are on a steady rise, befitting the Asian century. The small size of Japanese authors is further limited by the less frequent mutual citations among Japanese authors in comparison to the far more frequent 
Chinese authors' mutual citations, with American authors located in the middle (Ken Kymlica of Taylor \& Francis, Tokyo, conversation with me, 10 July 2018).

Last Issue: This last issue has two special issues: (1) 'The Wilsonian Moment in Japan, 1912-1952' (Takashi Inoguchi) and (2) 'Authoritarian deliberation revisited' (Baogang He). They delve into one of the key issues: liberal international order and deliberative democracy in the two countries whose respective weight are bound to increase in each respective domain, regardless of the names to be attached in the near future. Both special issues, plus some more, had been envisaged earlier. But with my transition from the University of Niigata Prefecture to Oberlin University (Tokyo) made it virtually impossible to keep the editorship intact and to have more special issues published in this journal. Fortunately, Junko Kato (University of Tokyo) and Christina Davis (Harvard University) will begin their term in 2019. Bon voyage!

Lastly, but most importantly, I would like to express my heartfelt gratitude to all those who submitted and reviewed manuscripts. They are the real makers of the journal. This is my sincere belief, as the journal is de facto devoid of the backing of a society or an academic association. Nevertheless, my sincere gratitude naturally goes to the Leviathan Japanese politics group that entrusted me by giving me full reins in running the journal. Cambridge University Press should receive all the praise for sustaining the journal from its inception, in particular Patrick McCartan and David Mainwaring. In closing, I am honored to have been a part of this academic undertaking. Thank you.

Cite this article: Inoguchi T (2018). Reflecting on nineteen years as editor of the Japanese Journal of Political Science (20002018). Japanese Journal of Political Science 19, 563-564. https://doi.org/10.1017/S1468109918000324 